\title{
MOBILIDADE SUSTENTÁVEL \\ CALÇADAS: ESPAÇOS DESTINADOS AOS DESBRAVADORES URBANOS NO BAIRRO DE SANTO AMARO
}

\author{
SUSTAINABLE MOBILITY \\ SIDEWALKS: INTENDED SPACES FOR THE URBAN \\ PATHFINDERS IN SANTO AMARO DISTRICT
}

\section{Adrielli França Da Silva}

Arquiteta e Urbanista graduada pelo Centro Universitário Fiam Faam.

email: adriellifranca.arq@gmail.com

\begin{abstract}
RESUMO
Os espaços de passeio no ambiente urbano destinados aos pedestres parecem ter sido resultado de um grande improviso dentro das questões de estruturação dos meios de circulação da cidade de São Paulo. Inicialmente as calçadas não eram destinadas para as pessoas trafegarem e sim as ruas, todavia com o aumento da indústria automobilística, as ruas passaram a ser projetadas prioritariamente para os automóveis, deixando em segundo plano as estruturas estabelecidas para a circulação de pessoas. As ações do poder público durante anos estiveram voltadas ao conforto do automóvel, direcionando a responsabilidade das calçadas aos proprietários dos lotes, definindo alguns parâmetros básicos que ainda hoje, raramente são seguidos, conformando caminhos sem unidade, desconexos e irregulares. Essa transmissão de responsabilidade mostra claramente o valor que se dá ao pedestre - basicamente nenhum - pois nem sequer existe a preocupação em disponibilizar uma via decente para ele trafegar em segurança e conforto. Santo Amaro foi escolhido para análise por ser um território extremamente diversificado quanto ao uso e a forma de ocupação e por suas características topográficas e de intenso movimento de pessoas. Assim, foi feito uma análise das calçadas da região através de diversas tipologias de pedestres, a fim de identificar dificuldades específicas e gerais de locomoção no bairro. Foram percorridos aproximadamente 12 quilômetros de calçadas no bairro, onde foi possível agrupá-las em 3 condições principais: Calçadas Adequadas; Calçadas Inadequadas com Potencial de Adequação e Calçadas Inadequadas sem potencial de Adequação. Constatou-se que as áreas com grande potencial parecem estar à espera da conscientização de seus
\end{abstract}


cuidadores, os proprietários, ou apenas de uma aplicabilidade e fiscalização mais rigorosa de nossas legislações em vigência, afinal é direito do cidadão não apenas ir e vir mas ser servido de qualidade em quaisquer que sejam seu percurso.

Palavras-chave: calçadas; passeio público; mobilidade sustentável; pedestres.

\section{ABSTRACT}

Walking areas intended for pedestrians in the urban environment seem to have been the result of a great improvisation within the questions of the structure of transportation means in the City of São Paulo. Initially the sidewalks were not intended for pedestrian traffic but the streets. However, with the rise of the automobile industry, the streets began to be designed primarily for cars and the structures established for the movement of people were put in the second plan. The actions of the authorities were focused on the comfort of the cars for many years, leaving the responsibility of the sidewalks to the owners of lands, setting some basic regulations that are rarely followed even today, paths without continuation, disconnected and irregular. This transmission of responsibility clearly shows the value given to the pedestrian - basically nothing - because there is no concern to provide a decent way for a safe and comfortable walk. Santo Amaro District was chosen for this analysis because it is an extremely diverse territory on the use and occupation way as well as topographical characteristics and intense traffic of people. Thus, it was analysed the sidewalks by considering various types of pedestrian, aiming to identify specific and general mobility difficulties on that site. It was covered about $12 \mathrm{~km}$ of sidewalks in that district, where it was possible to group them into three main conditions: Adequate Sidewalks; Inadequate Sidewalks with Suitability Potential; and Inadequate Sidewalks without Suitability Potential. It was concluded that those areas with great potential seem to be waiting for awareness of their caretakers, i.e. the owners, or just the application and strict enforcement of laws in force. Finally, it is a citizen's right not just come and go but to be served with quality whatever his paths are.

Keywords: Walkways; Promenade; Sustainable Mobility; Pedestrians. 
Do Outro Lado da Calçada

Do outro lado da calçada balança a Zona Sul Você caminha feito fada pura sedução

Desse lado da calçada o céu jamais é azul

Eu vou mas não levo p'ra casa o meu coração

É um absurdo tanto amar p'ra quem nunca se falou Coisas de quem vive sob o sol ou que passa a noite em vão

Os carros vedam meu olhar onde foi que você foi? Dobrou como uma folha de jornal a esquina da paixão.

(Rodrigo Saldanha | Cláudio Rabello)

\section{1 - DESENHO DAS CALÇADAS: COMO SURGIU?}

Os espaços de passeio no ambiente urbano destinados aos pedestres parecem ter sido resultado de um grande improviso dentro das questões de estruturação dos meios de circulação da cidade de São Paulo. De acordo com Moudon et al (sd), até a $2^{\text {a }}$ Guerra Mundial, as instalações para pedestres na forma de calçadas, passeios e faixas de travessia, normalmente acompanharam o desenvolvimento de áreas residenciais e comerciais em distritos urbanos e suburbanos. Antigamente as calçadas não eram para as pessoas trafegarem (Figura 1). Em filmes ou fotografias antigas que retratem qualquer rua comercial pode-se ver que as calçadas serviam de espaço para o feirante colocar as mercadorias, o dono do bar colocar as mesas, o engraxate colocar sua cadeira etc. As pessoas andavam na rua, negociando o espaço com os cavalos, bicicletas, crianças e com o incipiente tráfego automóvel. (SCHLICKMANN, 2014).

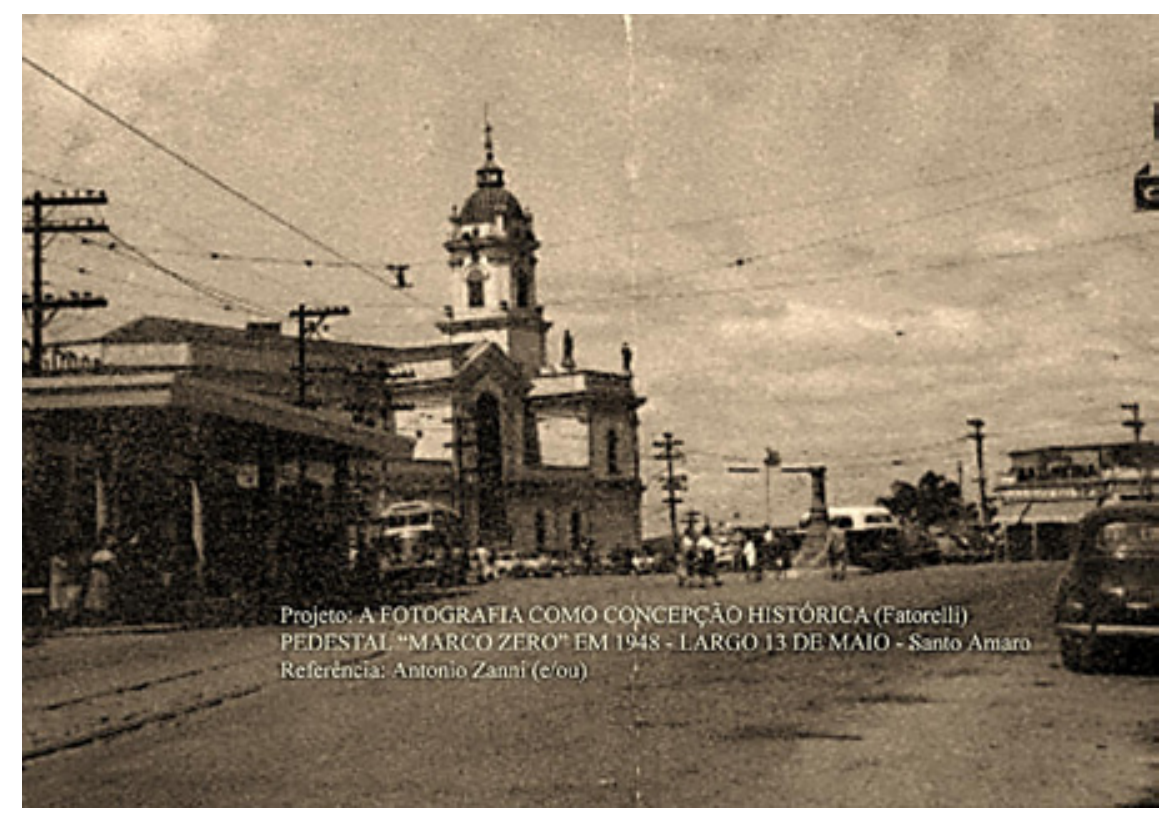

Figura 1 - Concepção Histórica do bairro de Santo Amaro.

Disponível em: <http:// carlosfatorelli27013. blogspot.com.br/2012/12/ o-pedestal-marco-zerode-santo-amaro-e.html> Acesso em out. 2015. 
Segundo Figueiredo et al. (2015), com o aumento da indústria automobilística, as ruas passaram a ser projetadas prioritariamente para os automóveis, deixando em segundo plano as estruturas destinadas para a circulação de pessoas. Assim, a falta de prioridade para o deslocamento de pedestres foi se agravando, à medida que as cidades foram se desenvolvendo, principalmente no fim da segunda metade do século XX, período em que ocorreu um aumento acelerado no processo de urbanização das cidades, como também o aumento da sua taxa de motorização. Leiva e Barbosa (2003), afirmam que esse tipo de enfoque trouxe diversas perdas em termos de qualidade ambiental e social para as cidades, uma vez que as ruas deixaram de ser utilizadas pelos seus habitantes como um local de trocas culturais e de lazer, transformando-se em espaços de passagem de veículos motorizados. Surge então um problema: onde colocar os pedestres?

Outro aspecto importante é da "economia urbana" do município onde o condutor/proprietário do veículo leva muita vantagem econômica sobre os outros habitantes do município, como nos gastos que o poder público tem com sinalização, recapeamento, desvios, polícia de trânsito e outras "benfeitorias" que servem exclusivamente ao automobilista (ou que servem ao pedestre em função do automobilista, como a faixa para travessia), bem como da dedicação de parte de seu corpo administrativo executivo para as secretarias de trânsito (Oshiro et. Al. 2009)

As ações do poder público durante anos estiveram focadas no leito carroçável, esta lógica levou a saturação das ruas e obrigou as prefeituras a rever esta forma de atuação. Desde logo, formou-se quase um consenso sobre a necessidade de melhorar a capacidade de atendimento do transporte público coletivo. Somou-se a isto a justa preocupação com o número expressivo de acidentes envolvendo pedestres, bem como a necessidade de atender ao igualmente elevado número de pessoas que possuem alguma restrição de mobilidade como cadeirantes, idosos, obesos e gestantes (BRASIL, 2009).

Segundo o último censo do IBGE (2000), 14,5\% da população brasileira apresenta algum tipo de deficiência física. Nesse novo panorama, era importante ampliar o horizonte dos estudos e ações no tocante à mobilidade urbana, valorizando a recuperação das calçadas (passeio público) das cidades, uma vez que a calçada é o espaço mais democrático e o que interliga todos os sistemas de transporte, seja particular ou público. 


\section{2 - SUSTENTABILIDADE E MOBILIDADE URBANA}

A dinâmica e qualidade dos espaços da cidade estão diretamente relacionados ao uso das calçadas, é normal a pessoa se sentir mais confortável e segura num local movimentado em diversos horários do que em espaços abandonados, ou seja, uma pessoa quando diz que uma cidade, ou parte dela, é perigosa, ela se refere basicamente ao fato de não se sentir segura em suas calçadas (JACOBS, 2011 pg.29).

Todos somos, em alguma hora do dia, pedestres. Ao sair de casa e andar até o ponto de ônibus, somos pedestres, do estacionamento até o escritório, somos pedestres e estamos expostos a inúmeros riscos, pois geralmente as calçadas não oferecem condições de segurança, conforto e mobilidade e acabam por inibir o que deveria ser o meio de transporte mais comum: "o caminhar" (SMPDS, 2012).

A sustentabilidade e a acessibilidade apontam, assim, para a condição de manutenção dos setores que a integram, operando e melhorando no longo prazo, constituindose em uma extensão do conceito utilizado na área ambiental, sendo também definida como o resultado de um conjunto de políticas de transporte e circulação que visam proporcionar o acesso amplo e democrático ao espaço urbano, por meio da priorização dos modos não motorizados e coletivos de transportes, de forma efetiva, que não gere segregações espaciais, socialmente inclusiva e ecologicamente sustentável, baseado nas pessoas e não nos veículos (Boareto, 2003).

\section{3 - ÂMBITO LEGAL: CALÇADAS, RESPONSABILIDADE DE QUEM?}

Hoje em dia, no Brasil, vivemos um dilema: a maioria dos municípios atribui ao proprietário do lote a construção e manutenção da calçada, definindo somente alguns parâmetros básicos como largura. Essa transmissão de responsabilidade mostra claramente o valor que damos ao pedestre - basicamente nenhum - pois nem sequer nos preocupamos em disponibilizar uma via decente para ele trafegar em segurança. O respeito pelas calçadas é um bom indicador do nível de democracia de uma nação (SCHLICKMANN, 2014).

Existem muitas leis que tratam da acessibilidade nos estados brasileiros. Um dos pilares dessa legislação, o decreto $n^{\circ} 5.296$ de 2004 (regulamenta duas leis, a n $n^{\circ} 10.098 \mathrm{e}$ $n^{\circ} 10.048$, sobre acessibilidade e atendimento prioritário, respectivamente) é incisivo 
quanto à obrigação de o Estado Nacional se adequar para atender às necessidades de cidadãos com deficiência. Isso inclui veículos de transporte coletivo, edificações de usos públicos e privados, livros, sites, espetáculos e atendimento.

Para que as calçadas do município fossem reformadas afim de garantir acessibilidade a todos os paulistanos, foi criado o PEC (Programa Emergencial de Calçadas), por meio da lei municipal $n^{\circ} 14.675$, de 2008. Por meio desse programa, a Prefeitura reforma trechos de calçadas nas chamadas Rotas Estratégicas e Estruturais. Essas áreas compreendem os principais serviços oferecidos nos bairros como escolas, bancos, correios, postos de saúde, paradas de embarque e desembarque de passageiros. Referidas rotas foram determinadas a partir de um sistema logístico de base de dados elaborado e gerido pela Secretaria Municipal da Pessoa com Deficiência e Mobilidade Reduzida (SMPED), em 2006 (BRASIL, 2015).

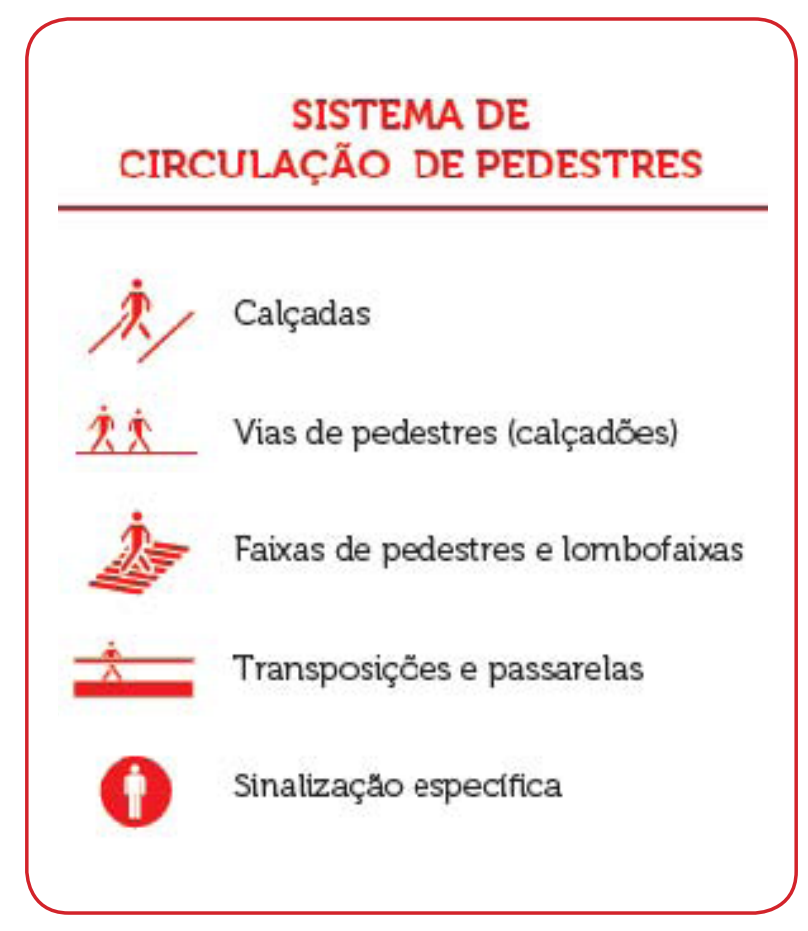

Segundo o atual Plano Diretor Estratégico de São Paulo 2014, o Sistema de Circulação de Pedestres é definido como o conjunto de vias e estruturas físicas destinadas à circulação de pedestres, tais como: as calçadas, as vias de pedestres (calçadões), as faixas de pedestres e lombofaixas, as transposições e passarelas e as sinalizações específicas (Figura 2).

Figura 2 - Sistema de circulação de pedestre PDE 2014.

Disponível em: <http://gestaourbana.prefeitura.sp.gov. br/texto-da-lei-com-hyperlinks/> Acesso em out. 2015.

As ações estratégicas do Sistema de Circulação de Pedestres estão principalmente direcionadas a garantir segurança a qualquer pessoa, aumentar o espaço das calçadas, padronizá-las de forma a garantir uma continuidade visual e material do passeio e melhorar a integração com os outros sistemas de transporte público, conforme o Artigo 232 do Plano Diretor Estratégico de São Paulo: 
Art. 232. As ações estratégicas do Sistema de Circulação de Pedestres são:

I - melhoria do acesso e do deslocamento de qualquer pessoa com autonomia e segurança pelos componentes do Sistema de Circulação de Pedestres;

II - integração do sistema de transporte público coletivo com as calçadas, faixas de pedestre, transposições e passarelas, visando ao pleno acesso do pedestre ao transporte público coletivo e aos equipamentos urbanos e sociais;

III - ampliação das calçadas, passeios e espaços de convivência;

IV - redução de quedas e acidentes relacionados à circulação de pedestres junto aos componentes do sistema;

$V$ - padronização e readequação dos passeios públicos em rotas com maior trânsito de pedestres;

$\mathrm{VI}$ - integração entre o sistema de estacionamento de bicicletas (paraciclos e bicicletários) e as calçadas, visando ao pleno acesso de ciclistas aos estabelecimentos.

Embora a adequação das calçadas seja obrigação dos munícipes, é a Prefeitura que executa e paga as reformas desses locais. Porém, após a reforma, a manutenção desses passeios continua sob responsabilidade do cidadão, que pode ser multado se não o fizer (BRASIL, 2015).

\section{4 - PASSEIO IDEAL}

A calçada ideal é aquela que garante o caminhar livre, seguro e confortável a todos os cidadãos. Em São Paulo, o Decreto 45.904 de 2005, criou uma padronização para os passeios públicos da cidade. Por essa regulamentação, as calçadas paulistanas devem ser feitas com alguns pisos pré-estabelecidos, com especificações de largura, inclinação e faixas de ocupação de modo que todas as pessoas - como portadores de algum tipo de deficiência ou não - consigam circular com autonomia e segurança (BRASIL, 2015).

A calçada é o caminho que nos conduz ao lar, ela é o lugar por onde transitam os pedestres na movimentada vida cotidiana, é por meio dela que as pessoas chegam aos diversos pontos do bairro e da cidade (SMPDS, 2012). 
Para organizar o passeio público, a Prefeitura definiu um novo padrão arquitetônico que divide as calçadas em faixas. As calçadas com até 2 metros de largura serão divididas em 02 faixas diferenciadas por textura ou cor e as com mais de 2,00 metros, em 03 faixas, também diferenciadas, como mostra a ilustração abaixo (Figura 3).

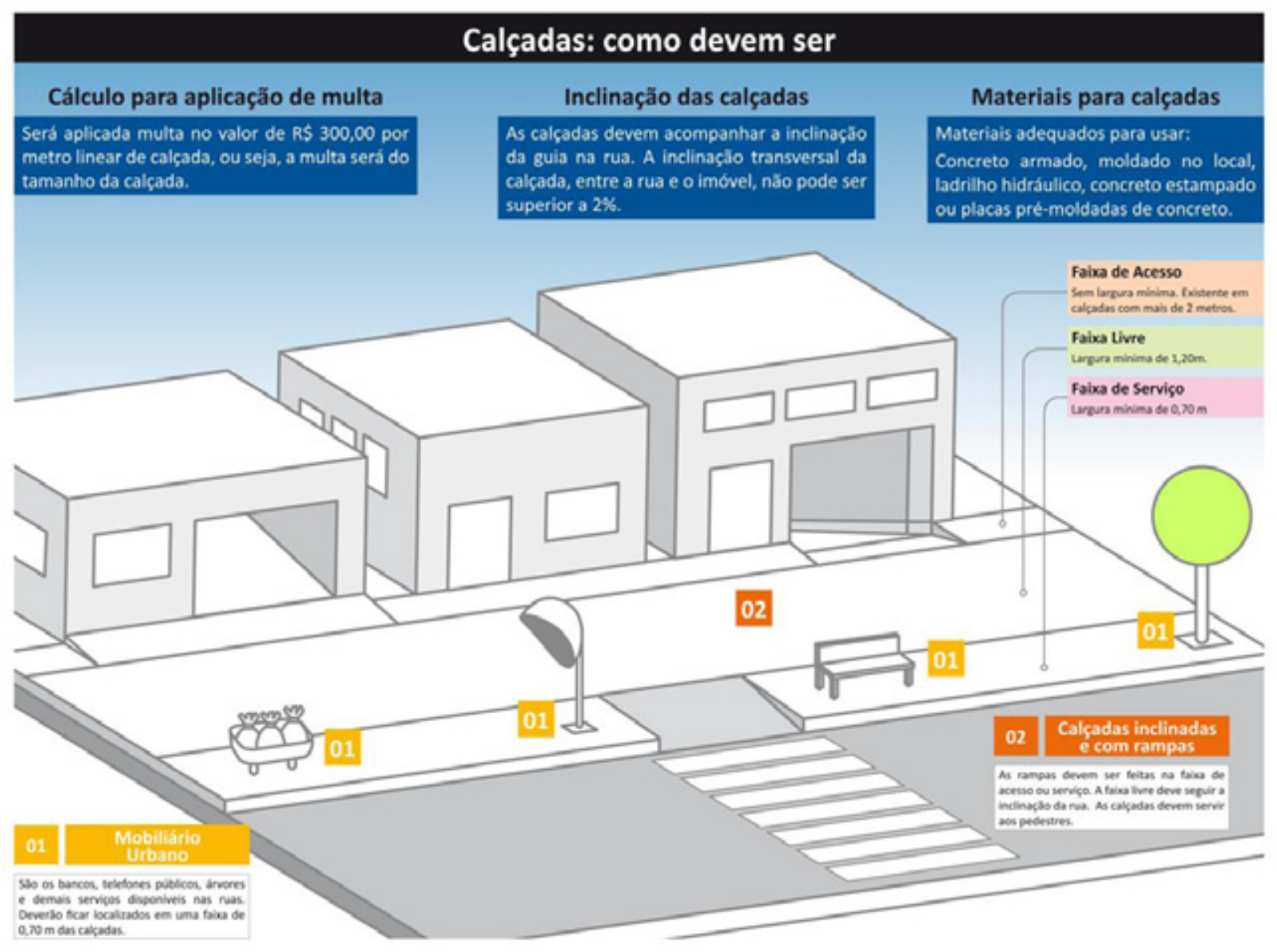

Figura 3 - llustração de como as calçadas devem ser.

Disponível em: <http://solucoesparacidades.com.br/wp-content/uploads/2013/04/Nova-Cartilha.pdf>. Acesso em out. 2015.

$1^{\text {a }}$ Faixa de serviço: Destinada à colocação de árvores, rampas de acesso para veículos ou portadores de deficiências, poste de iluminação, sinalização de trânsito e mobiliário urbano como bancos, floreiras, telefones, caixa de correio e lixeiras.

2a Faixa livre: A faixa livre é destinada exclusivamente à circulação de pedestres, portanto deve estar livre de quaisquer desníveis, obstáculos 
físicos, temporários ou permanentes ou vegetação. Deve atender às seguintes características:

- possuir superfície regular, firme, contínua e antiderrapante sob qualquer condição;

- possuir largura mínima de 1,20 m (um metro e vinte centímetros);

- ser contínua, sem qualquer emenda, reparo ou fissura. Portanto, em qualquer intervenção o piso deve ser reparado em toda a sua largura seguindo o modelo original.

- se a calçada for inclinada a faixa livre deve seguir a inclinação da rua.

$3^{\text {a }}$ Faixa de acesso: Área em frente ao seu imóvel ou terreno, onde podem estar a vegetação, rampas, toldos, propaganda e mobiliário móvel como mesas de bar e floreiras, desde que não impeçam o acesso aos imóveis. É portanto uma faixa de apoio à sua propriedade.

Para uma pessoa com deficiência visual, uma das atividades mais difíceis é sua locomoção independente, utilizando as informações e os recursos disponíveis. Essas informações são captadas por meio do uso das percepções táteis, sendo feita também pela bengala e pelos pés. A sinalização tátil no piso pode ser do tipo de alerta ou direcional e ambas devem ter cor contrastante com o resto do pavimento.

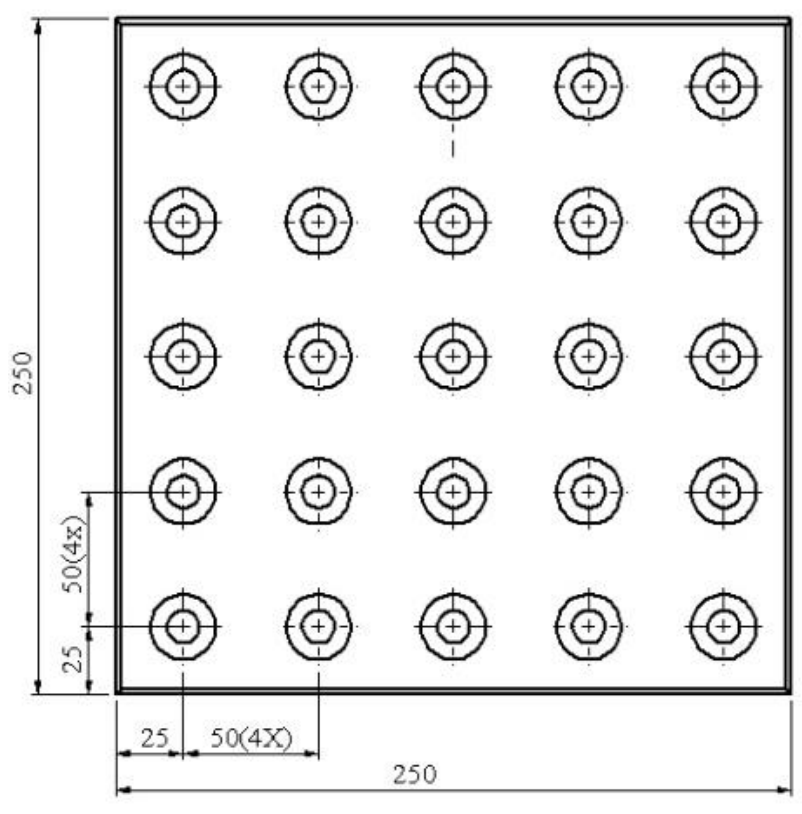

Piso tátil de alerta é um recurso que auxilia a pessoa portadora de deficiência visual quanto ao seu posicionamento na área da calçada. Ele deve ser instalado em áreas de rebaixamento de calçada, travessia elevada, canteiro divisor de pistas ou obstáculos suspensos (Figura 4).

Figura 4 - Piso tátil de alerta.

Disponível em: <http://www.mudras.com.br/piso. html> Acesso em out. 2015. 
O piso direcional é instalado formando uma faixa que acompanha o sentido do deslocamento e tem a largura entre $25 \mathrm{~cm}$ a $60 \mathrm{~cm}$. Esta faixa deve ser utilizada em áreas de circulação, indicando o caminho a ser percorrido e em espaços muito amplos, sempre que houver interrupção da face dos imóveis ou de linha guia identificável, como por exemplo, nos postos de gasolina (Figura 5).

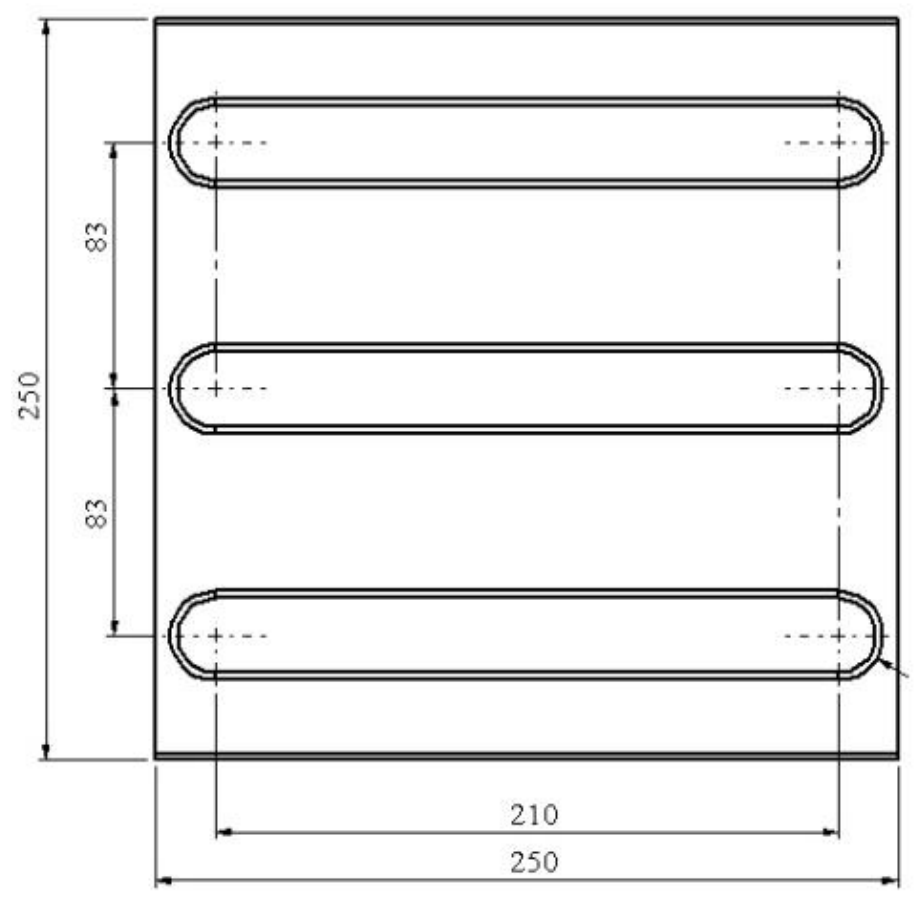

Figura 5 - Piso tátil de direcional. Disponível em: <http://www.mudras.com. br/piso.html> Acesso em out. 2015.

A presença de árvores nas calçadas é importante, pois elas contribuem para melhorar o meio ambiente de nossa cidade e, nos dias de chuva, facilitam a retenção das águas. Porém, “compete à Prefeitura plantá-las” ou repará-las e, neste caso, o técnico da subprefeitura estará atento à Lei 10. 365/87 e a duas necessidades básicas:

I. A dimensão da espécie escolhida deve estar adequada à largura da calçada.

II. Não cimentar a base da árvore, para não prejudicar o desenvolvimento da mesma. No caso, deve haver grama ou ser instalada uma grelha, que facilita o fluxo dos pedestres.

Nas ruas onde não há um fluxo muito grande de pedestres as faixas de Serviço e Acesso poderão ser ajardinadas seguindo o padrão de "calçadas verdes". As faixas 
ajardinadas não devem possuir arbustos que prejudiquem a visão e o caminho do pedestre. Porém, para construir uma calçada verde, o munícipe deve estar atento à lei 13.646 de 2003 e aos seguintes aspectos:

I. Para receber uma faixa de ajardinamento, o passeio deverá ter largura mínima de $2 \mathrm{~m}$ (dois metros); e para receber duas faixas de ajardinamento, largura mínima de $2,5 \mathrm{~m}$.

II. As faixas ajardinadas não poderão interferir na faixa livre que deverá ser contínua e com largura mínima de $1,20 \mathrm{~m}$ (um metro e vinte centímetros).

III. As faixas ajardinadas não devem possuir arbustos que prejudiquem a visão ou com espinhos que possam atrapalhar o caminho do pedestre.

IV. Para facilitar o escoamento das águas em dias chuvosos as faixas não podem estar muradas.

No que se refere ao material, as calçadas hoje podem contribuir na drenagem das águas sendo permeáveis ou drenantes. Basta escolher o material adequado e preparar uma base para absorver essas águas. Os materiais utilizados são definidos pela subprefeitura conforme critérios abaixo (BRASIL 2014):

- Apenas para vias Locais e Coletoras - Placas Pré-Moldadas de Concreto, placas pré-fabricadas de concreto de alto desempenho, fixas ou removíveis, para piso elevado ou assentamento diretamente sobre a base;

- Para todos os tipos de vias - Ladrilho Hidráulico Placa de concreto de alta resistência ao desgaste para acabamento de pisos, assentada com argamassa sobre base de concreto;

- Para todos os tipos de vias - Concreto Armado Moldado no Local, a calçada pode ser executada em concreto moldado no local. Ele pode ser "vassourado" ou receber estampas coloridas. Neste caso o piso recebe um tratamento superficial, executado no mesmo instante em que é feita a concretagem do pavimento, enquanto o concreto ainda não atingiu o início de pega. $O$ processo consiste em, através do uso 
de ferramental adequado, formas para estamparia e produtos de acabamento especiais, reproduzir cores e texturas variadas;

- Apenas para vias Locais e Coletoras - Pavimentos Intertravados Pavimento de blocos de concreto pré-fabricado por intermédio de ferramental, assentados sobre colchão de areia, travado por meio de contenção lateral e por atrito entre as peças;

\section{5 - TIPOS DE PEDESTRE}

Pedestre é a qualidade de se andar a pé, Gold (2003) especifica melhor este conceito quando caracteriza o Pedestre como qualquer pessoa se locomovendo a pé nas vias públicas. Como quase todos andam a pé, a palavra Pedestre significa uma condição temporária de cada membro da população e não uma determinada categoria da população.

Segundo Ferreira e Shimoishi (1996), os Pedestres são todas as pessoas que se deslocam a pé pelos espaços públicos abertos, inclusive o proprietário do veículo particular individual, que em algum momento de seu percurso, dependendo do destino, passa da condição de motorista para a condição de pedestre. Melo et. al. (2004), afirma que "os Pedestres formam um grupo heterogêneo de usuários do sistema viário, que engloba pessoas de diferentes faixas etárias, sexos, nacionalidades e níveis socioeconômicos. Este grupo se divide ainda em diferentes níveis de condições físicas de utilização do sistema viário, como por exemplo, pessoas idosas e portadores de necessidades especiais - PNE's".

Já Silva e Lara (2005) apud Amiralian, 2000, definem Pedestres como todas as pessoas que se deslocam pelos espaços públicos abertos, independentemente das suas condições sensoriais e/ou motoras, do tempo de permanência, ou do modo de apropriação espacial. São também consideradas Pedestres pessoas transportadas em carrinhos de bebês, patins, patinetes, triciclo, bicicleta com rodas de diâmetro inferior a 14 polegadas, ou outro veículo similar. Todas as definições acerca do conceito de Pedestre revelam a importância que este tem no ambiente de circulação das cidades e para possibilitar e estimular a locomoção a pé em uma localidade é necessário a provisão de uma infraestrutura compatível com as necessidades de locomoção dos seus pedestres. 
Na Classificação Internacional de deficiências, incapacidades e desvantagens: um manual de classificação das consequências das doenças (CIDID) evitou-se utilizar a mesma palavra para designar as deficiências, incapacidades e desvantagens. Assim, para uma deficiência foi adotado um adjetivo ou substantivo, para uma incapacidade, um verbo no infinitivo e para uma desvantagem, um dos papéis de sobrevivência no meio físico e social (AMIRALIAN, 2000).

\begin{tabular}{|c|c|c|}
\hline Deficiência & Incapacidade & Desvantagem \\
\hline $\begin{array}{l}\text { Da linguagem } \\
\text { Da audiçao (sensorial) } \\
\text { Da visào }\end{array}$ & $\begin{array}{l}\text { De falar } \\
\text { De ouvir (de comunicação) } \\
\text { De ver }\end{array}$ & $\mathrm{Na}$ orientaçāo \\
\hline Músculoesquelética (física) & \multirow{2}{*}{$\begin{array}{l}\text { De andar (de locomoção) } \\
\text { De assegurar a subsistência no lar } \\
\text { (pusiço do curpo e destreza) } \\
\text { De realizar a higiene pessoal } \\
\text { De se vestir (cuidado pessoal) } \\
\text { De se alimentar }\end{array}$} & $\begin{array}{l}\mathrm{Na} \text { independência física } \\
\mathrm{Na} \text { mobilidade }\end{array}$ \\
\hline De órgàcs (orgânica) & & Nas atividades da vica diária \\
\hline $\begin{array}{l}\text { Intelectual (mental) } \\
\text { Psicológiza }\end{array}$ & $\begin{array}{l}\text { De aprender } \\
\text { De perceber (aptidōes particulares) } \\
\text { De memorizar } \\
\text { De relacionar-se (comportamento) } \\
\text { De ter consciência }\end{array}$ & $\begin{array}{l}\mathrm{Na} \text { capacidade ocupicional } \\
\mathrm{Na} \text { integração social }\end{array}$ \\
\hline
\end{tabular}

Figura 6 - Distinção Semântica de Conceitos.

Disponível em: <http://dx.doi.org/10.1590/S0034-89102000000100017 > Acesso em out. 2015.

\section{6 - O BAIRRO CIDADE}

\subsection{Breve Histórico do Bairro}
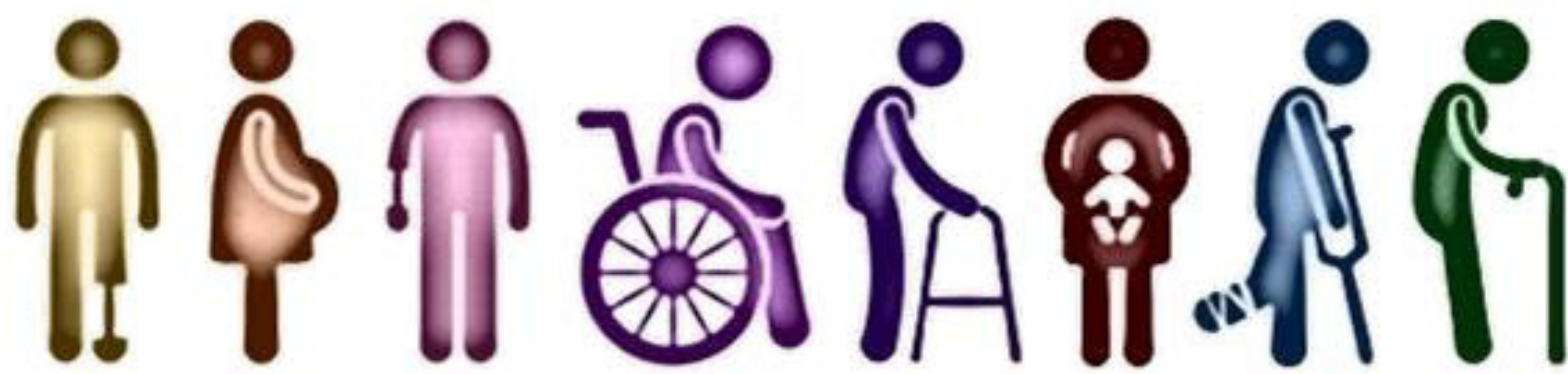

A origem de Santo Amaro está ligada a uma aldeia indígena à margem do rio Jurubatuba ou Jeribatiba. O primeiro nome do rio Pinheiros foi Jeribatiba ou Jurubatuba, que em tupi significa "muitos jerivás", um tipo de palmeira de porte médio comum na região, que chegou a identificar um rio (PONCIANO, p. 249, 2004). 
O bairro recebeu ao longo dos séculos nomes como: Virapuera, Jeribatiba, Ibirapuera, Santo Amaro de Virapuera e, por fim, Santo Amaro.

Jeribatiba (Santo Amaro) foi um dos três locais ocupados pelos jesuítas após a fundação da Vila de São Paulo em 1554. Pelo grande número de moradores, passou a constituir um povoado, sendo construída uma capela na região do Cupucê. Em 1831, Santo Amaro passou a ser considerado um município, permanecendo assim até 22 de fevereiro de 1935, quando o interventor Armando de Sales de Oliveira, resolveu anexá-lo à cidade de São Paulo (PONCIANO, p. 251, 2004). Logo após essa medida foram feitos muitos movimentos pela emancipação do bairro, todavia sem sucesso, e atualmente são raros os habitantes que querem o retorno de Santo Amaro à categoria de município da capital paulista.

\subsection{Análise Urbana Santo Amaro}

Pertencente à subprefeitura de Santo Amaro, o bairro possui área territorial de $15,60 \mathrm{~km}^{2}$ e cerca de 71.560 habitantes, porém a população flutuante é muito maior. Estima-se que a população flutuante no Largo Treze de Maio alcance um milhão de pessoas diariamente, visto que a região é um grande centro de comércio popular e de passagem da zona sul paulistana, por sua posição estratégica, que abriga dezenas de terminais de ônibus municipais e intermunicipais, além das linhas de trem e metrô. (MORATO et al. 2004). (Figura 7) 


\section{SISTEMA TRANSPORTE PÚBLICO - REGIÃO DE ESTUDO}

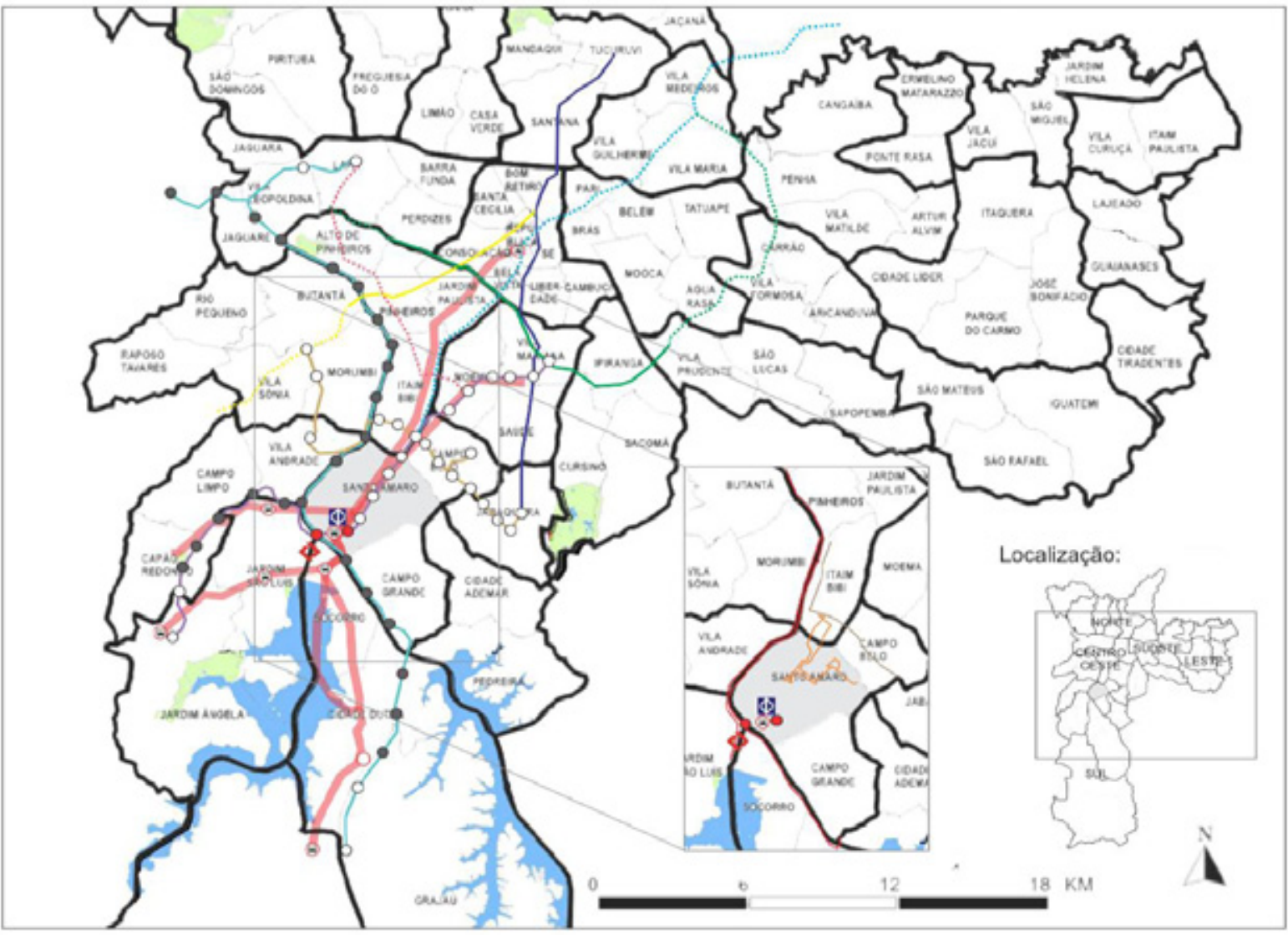

\section{LEGENDA}

\section{(1) Metrô}

Linha 5 - Lilás (Jd. Ångela -- Chácara Klabin)

Linha 1 - Azul (Tucunuvi -- Jabaquara)

Linha 4 - Amarela (Luz - Taboåo da Serra)

Linha 2 - Verde (Cerro Corá -- Dutra)

Linha 20 - Rosa (Lapa - Moema)

\TREM

Linha 9 - Esmeralda (Jd. Ângela -- Chácara Klabin) MONOTRILHO

Linha 17 -Ouro (São Paulo Morumbi -- Jabaquara/ Congonhas)

ONIBUS

Corredor de Onibus

(4) Term. de Onibus

50) BICICLETA

Ciclovias

Ciclorrota

Ciclofaixa
- Estaçס̄es previstas até 2021

- Estaçóes existentes (2014)

- Estaçóes existentes que servem diretamente a região de intervenção

.......... Trechos previstos até 2021

Trechos existentes (2014)

REGIÃODEANÁLISE

-SANTOAMARO

fonte de dedos: www.metro.sp.gov.br vadebike.org

www.sptrans.com.br

MAPA - www mapasparacolorir com

elaboraçăc: Acervo próprio

Figura 7 - Mapa dos Sistema de Transporte Público do Município de São Paulo.

Elaborado pela autora 
Segundo a Subprefeitura de Santo Amaro a diversidade não é só da população que ali vive, onde é possível encontrar os extremos da pobreza e riqueza, essa característica existe também em relação a ocupação que mescla áreas residenciais, de comércio e serviço.

Aspectos de área central envolvem grande território do bairro e para melhor análise do potencial que esse espaço tem a contribuir ao tópico aqui tratado, fora definido um eixo de levantamento com $1 \mathrm{~km}$ de percurso, que é o adequado a se caminhar para chegar aos equipamentos de uso cotidiano. Segundo Gehl:

"O tamanho dos centros das cidades confirma a distância de 500 metros como um objetivo aproximado de uma caminhada aceitável. A grande maioria dos centros das cidades tem um quilômetro quadrado, correspondendo a uma área de $1 \times 1 \mathrm{~km}$. Isso significa que uma caminhada de um quilômetro ou menos levará os pedestres à maior parte dos serviços."

O mapa de uso e ocupação (Figura 8), mostra bem o caráter do subdistrito de Santo Amaro, onde a diversidade de ocupação é realmente perceptível. Na região norte, percebe-se uma grande área de vegetação do Clube Hípico da região, e um caráter predominantemente residencial de médio porte no seu entorno imediato com bom aspecto de conservação. Bem próximo existe também um grande espaço com edifícios sem uso, criando junto com o clube privado e muralhado, uma barreira urbana que afasta o pedestre do local.

Já na região oeste existe a presença de galpões industriais, e consequentemente as construções residenciais ou de serviço e pequenos comércios estão, em sua maioria, degradadas ou vazias. Na região Leste há uma mistura de usos bastante proporcional, mas é notável a mudança, principalmente do uso residencial para o uso de serviço ou comércio.

Por fim, ao sul tem-se o grande e pulsante polo comercial da região, o Largo Treze. Região essa que proporciona um movimento intenso durante o horário comercial, e que durante a noite vira cenário de abandono e degradação. 


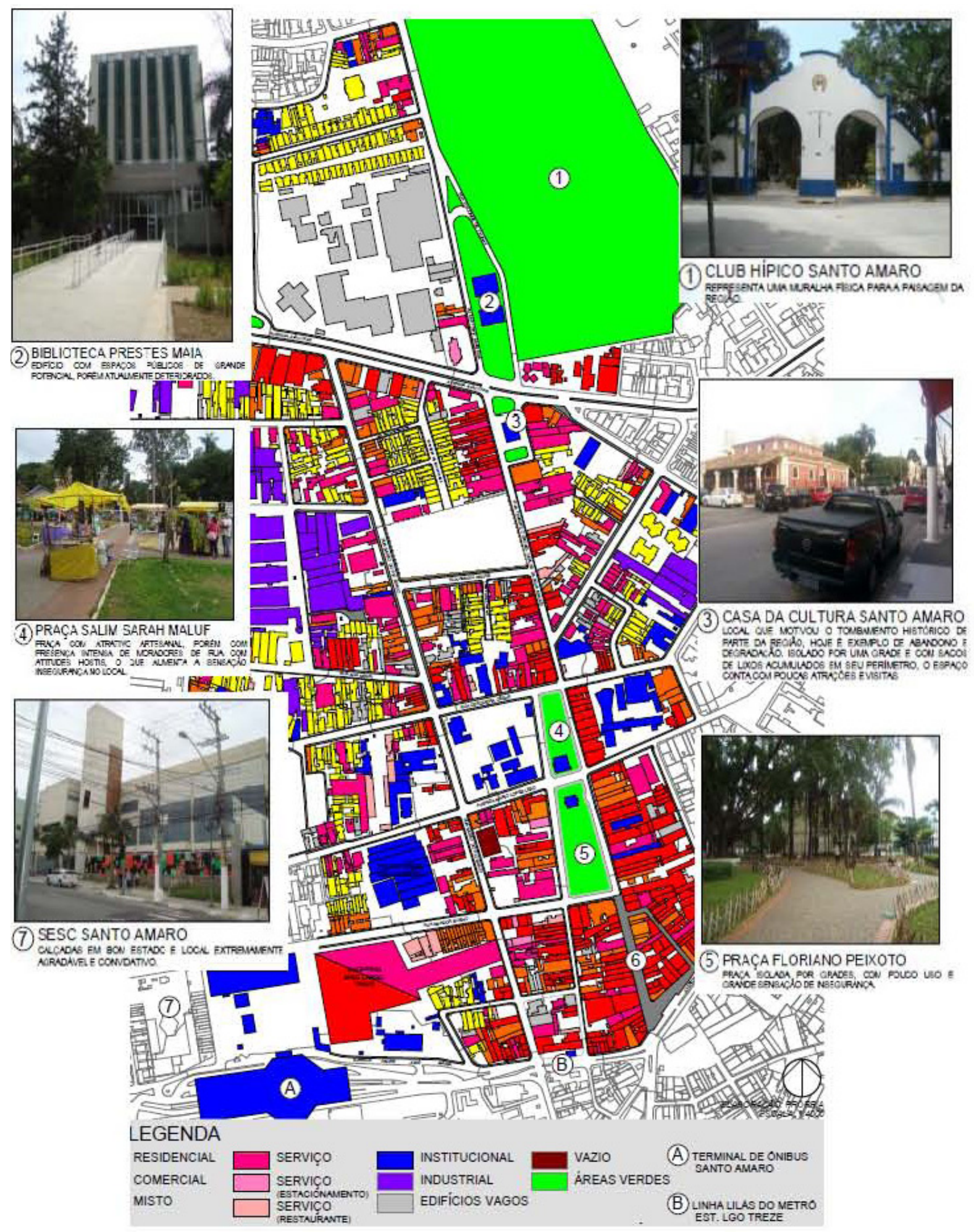

Figura 8 - Mapa de Uso e Ocupação do Solo. Elaborado pela autora.

Analisando o bairro do ponto de vista das edificações percebe-se que o gabarito da região é bem uniforme e horizontalizado, devido a suas construções térreas ou térreo 
mais 1, o que cria uma paisagem bastante próxima e confortável para a "escala" do pedestre. Há uma leve tendência à verticalização no núcleo de comércio do Largo Treze, porém é ainda bem tímida (Figura 9). A tendência é essa "verticalização" se intensificar no local, pois com novas linhas ou estações do metrô e monotrilho, a região poderá atingir grande potencial de mobilidade, aumentando assim sua procura, motivo esse que normalmente impulsiona o adensamento.

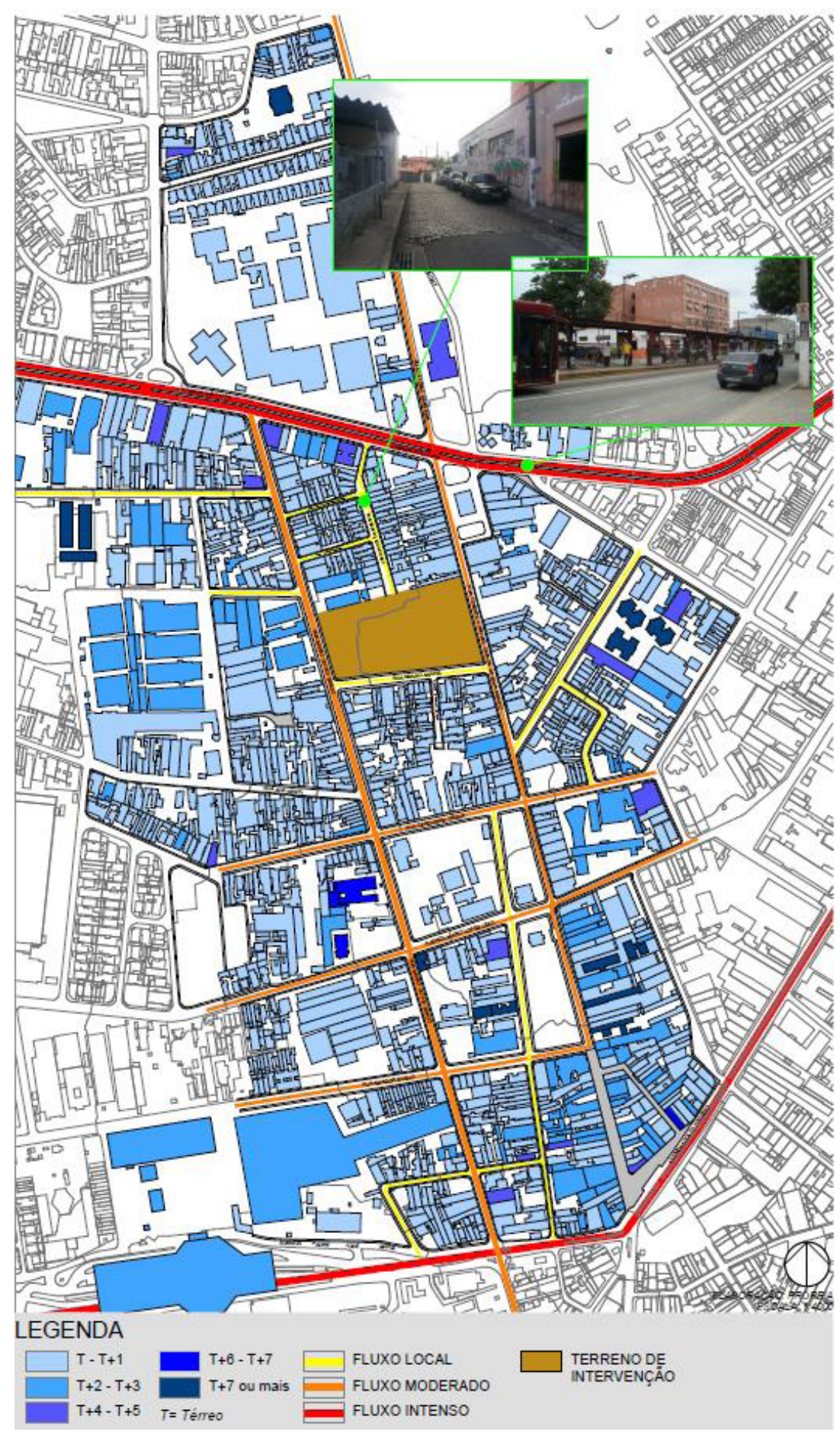

Figura 9 - Mapa de Gabarito. Elaborado pela autora. 
Na maior parte dos espaços percorridos no bairro a sensação ou é de grande insegurança, devido à degradação intensa dos espaços urbanos decorrentes de áreas industriais que acabam forçando uma ocupação decadente do entorno imediato e substituição de áreas residenciais por outras diversas; ou de intensa agitação concentrada principalmente nos arredores do comércio do Largo Treze. Infelizmente, o acúmulo de pessoas na cidade de São Paulo é muitas vezes sinônimo de degradação e vandalismo refletindo nas áreas verdes e nos bens públicos (Figura 10).

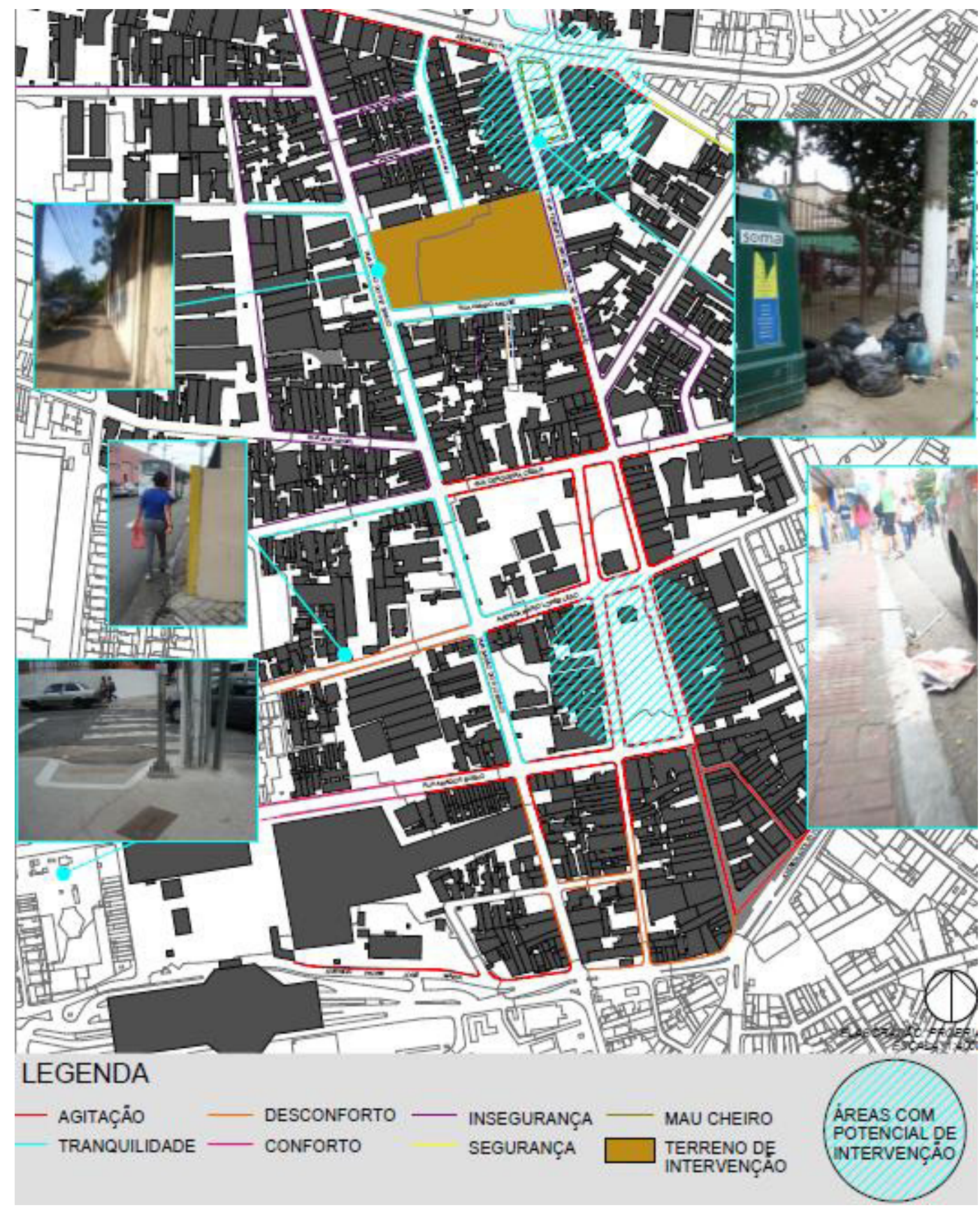

Figura 10 - Mapa de Sensações. Elaborado pela autora. 


\subsection{Estudo de Caso: Desbravadores do Bairro Santo Amaro.}

A análise das calçadas do bairro de Santo Amaro foi feita Utilizando-se dos relatos das dificuldades colhidas dos seus usuários e por meio dos parâmetros técnicos e legais que determinam um bom passeio público, afim de entender se o apontado como adequado atende bem todos os tipos de pedestres e se o que é determinado em forma de lei é o que acontece na prática. Conforme os parâmetros abaixo:

- Acessibilidade - Assegurar completa mobilidade aos usuários, sobretudo pessoas com deficiência ou com mobilidade reduzida;

- Dimensionamento - Atendendo às normas técnicas quanto à largura mínima e inclinação transversal;

- Qualidade - Atributo que qualifica a percepção do passeio no entorno criando uma identidade espacial;

- Segurança - Proporcionar segurança ao ato de andar, ou seja, por meio de materiais de revestimento adequados, como também pela boa distribuição de seus mobiliários, dos elementos urbanos e iluminação pública;

- Continuidade - Constituir rota de deslocamento acessível aos pontos de maior interesse coletivo, guardando seus aspectos estéticos e funcionais em harmonia;

- Espaço de socialização - Propiciar espaços de encontro e interação entre pessoas;

- Desenho da paisagem - Organização de todos os elementos das vias de modo a torná-las ambientalmente confortáveis, propiciando microclimas a'gradáveis e conforto visual.

- Permeabilidade - As calçadas podem contribuir na drenagem das águas sendo permeáveis ou drenantes, basta escolher o material adequado e preparar uma base para absorver estas águas.

- Arborização - É preciso combater as chamadas "ilhas de calor" que se formam onde o solo é impermeabilizado e falta arborização. Para isso é importante plantar árvores onde for possível.

- Beleza - Uma rua fica mais bonita e humana quando suas calçadas são acessíveis e padronizadas. 
A abordagem foi feita em 3 dias diferentes e em três pontos distintos de chegada ao núcleo do bairro, tais como: 1. Corredor de ônibus da Av. João Dias na parada Antônio Bandeira; 2. Terminal de Ônibus Santo Amaro; 3. Linha Lilás do metrô na estação Largo Treze; Três locais importantes na interação modal da região. Nessas ocasiões fora feito um pedido ao transeunte de colaboração com a pesquisa, em que o mesmo respondia a 3 breves questões e autorizava que pudesse acompanhá-lo à sua próxima parada, para que fosse possível uma análise técnica dos espaços percorridos e para que as dificuldades gerais dos pedestres participantes pudessem ser percebidas.

Foram percorridos aproximadamente 12 quilômetros de calçadas no bairro, e em relação aos parâmetros técnicos foi possível agrupá-las em 3 condições principais: Calçadas Adequadas; Calçadas Inadequadas com Potencial de Adequação e Calçadas Inadequadas sem potencial de Adequação, dispostos em sua proporção no mapa de síntese a seguir (Figura 11).

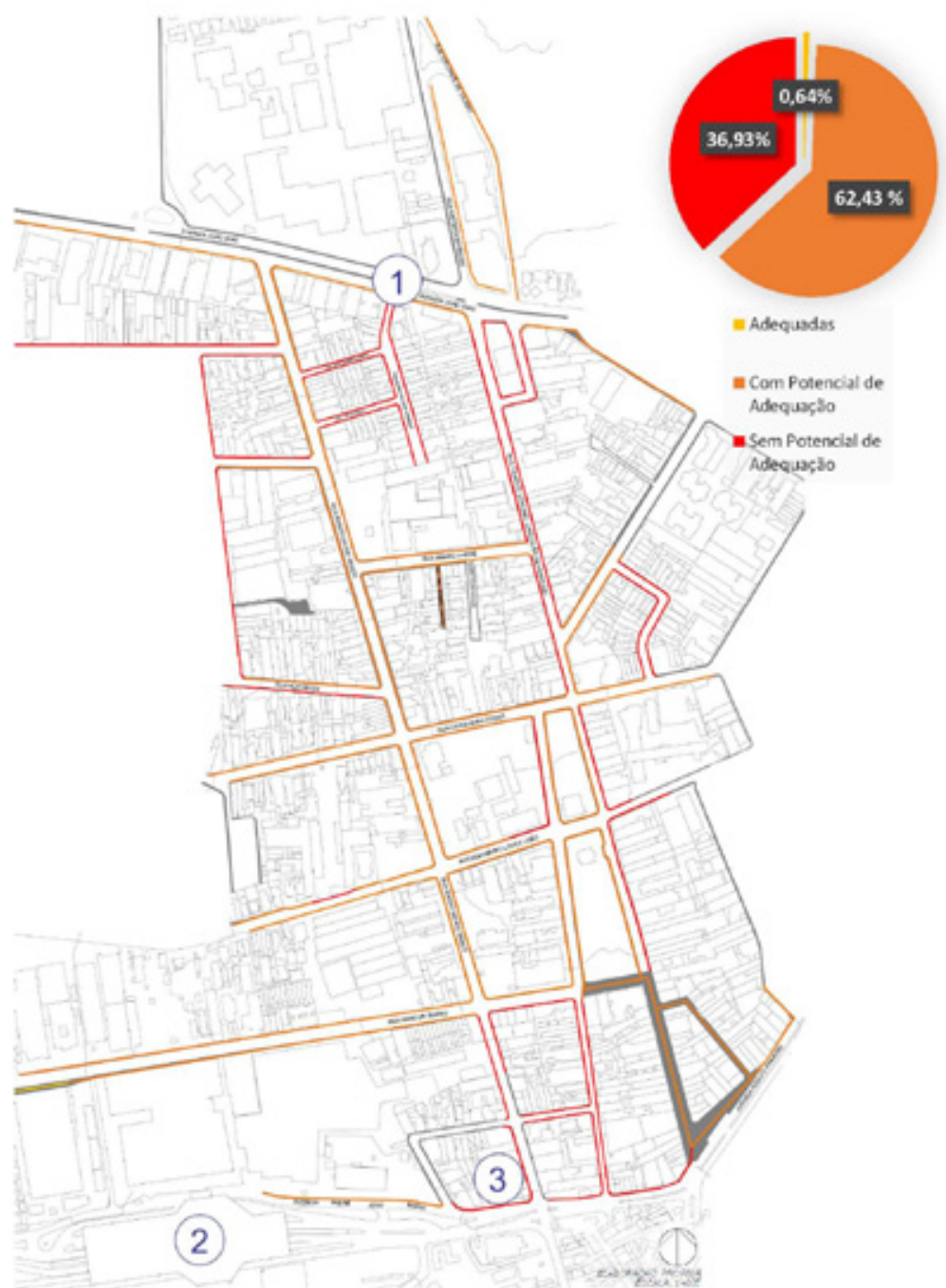

Figura 11 - Mapa Síntese de Análise das calçadas.

Elaborado pela autora. 
A primeira, a raríssima qualidade de "Calçada Adequada", verifica-se um atendimento completo aos parâmetros indicados na legislação, com piso permeável, piso tátil bem posicionado, dimensionamento adequado e seguro das 3 faixas de um passeio público, arborizado e acessível, como podemos ver na Figura 12, na qual um Idoso consegue facilmente se locomover nesse espaço, que não por coincidência é mantido pelo SESC (Serviço Social do Comércio) Santo Amaro e representa menos que 1\% das calçadas.
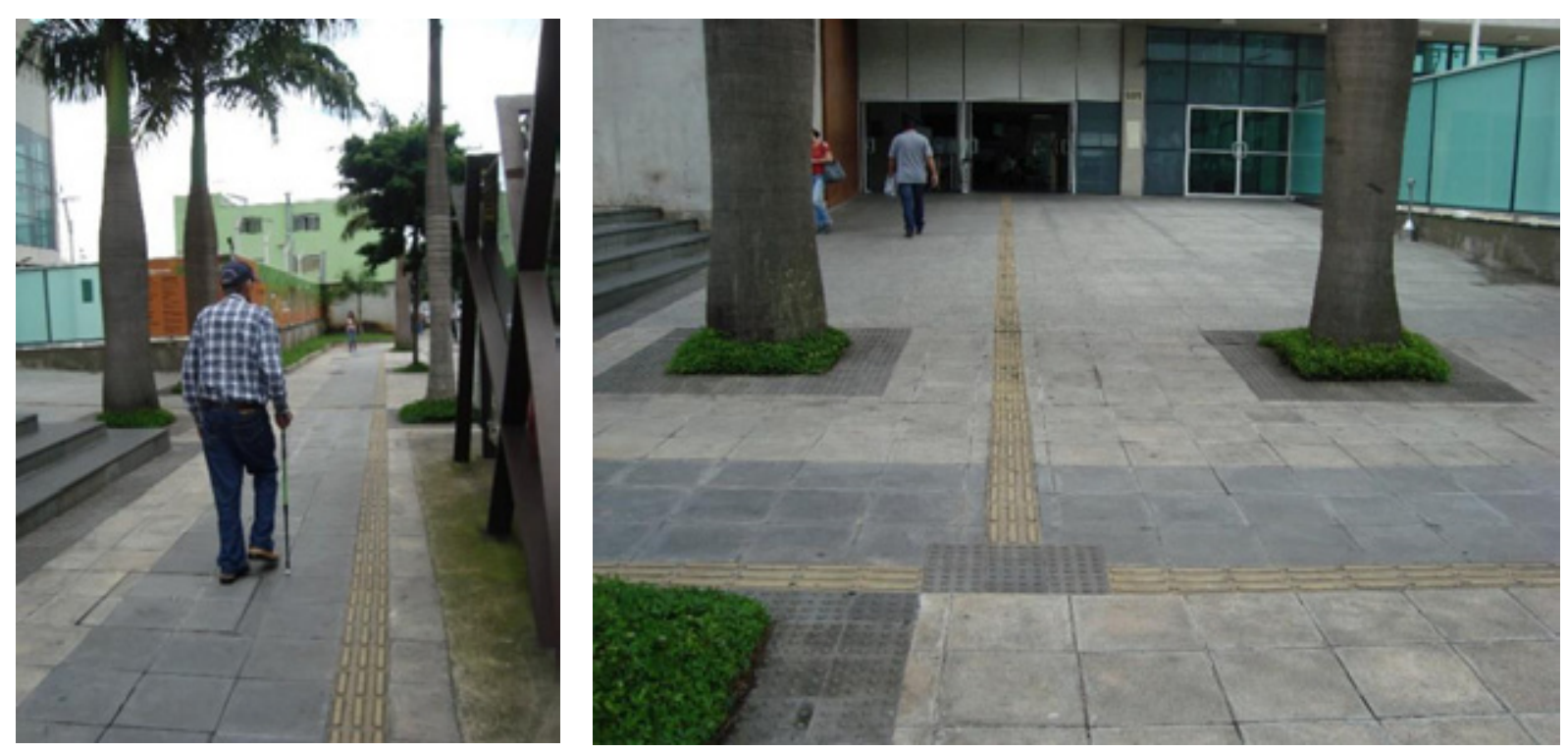

Figura 12 - Calçada SESC Santo Amaro - Idoso. Foto: Adrielli França. 2015

A predominância do cenário são as "Calçadas Não Adequadas" aos usuários, porém é possível dividi-la em 2 subgrupos: aquelas COM potencial de adequação $(62,43 \%)$ e as SEM potencial de adequação (36,93\%), imaginando que para esse último grupo não existe solução na área já destinada ao passeio, sendo necessária a extensão da mesma para o leito carroçável, já que sua dimensão é totalmente inadequada e concorre com todos os equipamentos públicos, descarte de sacos de lixo e até placas de anúncios do comércios. Nessas calçadas os pedestres são conduzidos à disputa nas ruas com os carros, comércio ambulante e com os próprios transeuntes, está travada aí uma disputa desleal e arriscada (Figura 13). 

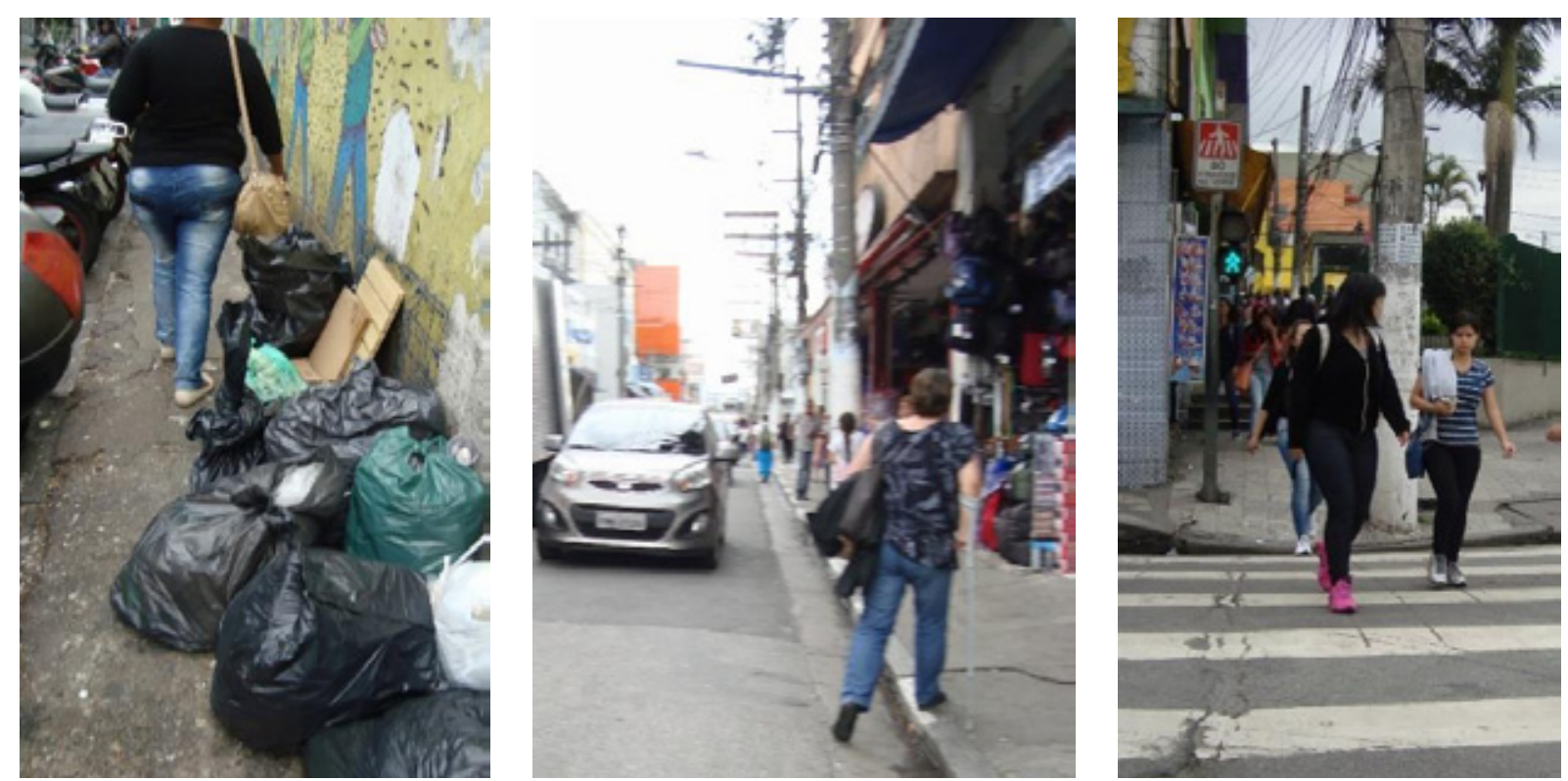

Figura 13 - Calçadas inadequadas - Pessoa sem Limitações físicas; Pessoa com Mobilidade Reduzida e Deficiente Auditiva. Foto: Adrielli França. 2015

É motivo de esperança porém, saber que mais da metade das calçadas analisadas possuem espaço e potencial na paisagem e na condição topográfica da região de se adequar aos parâmetros de conforto e segurança de seus usuários (Figura 14).
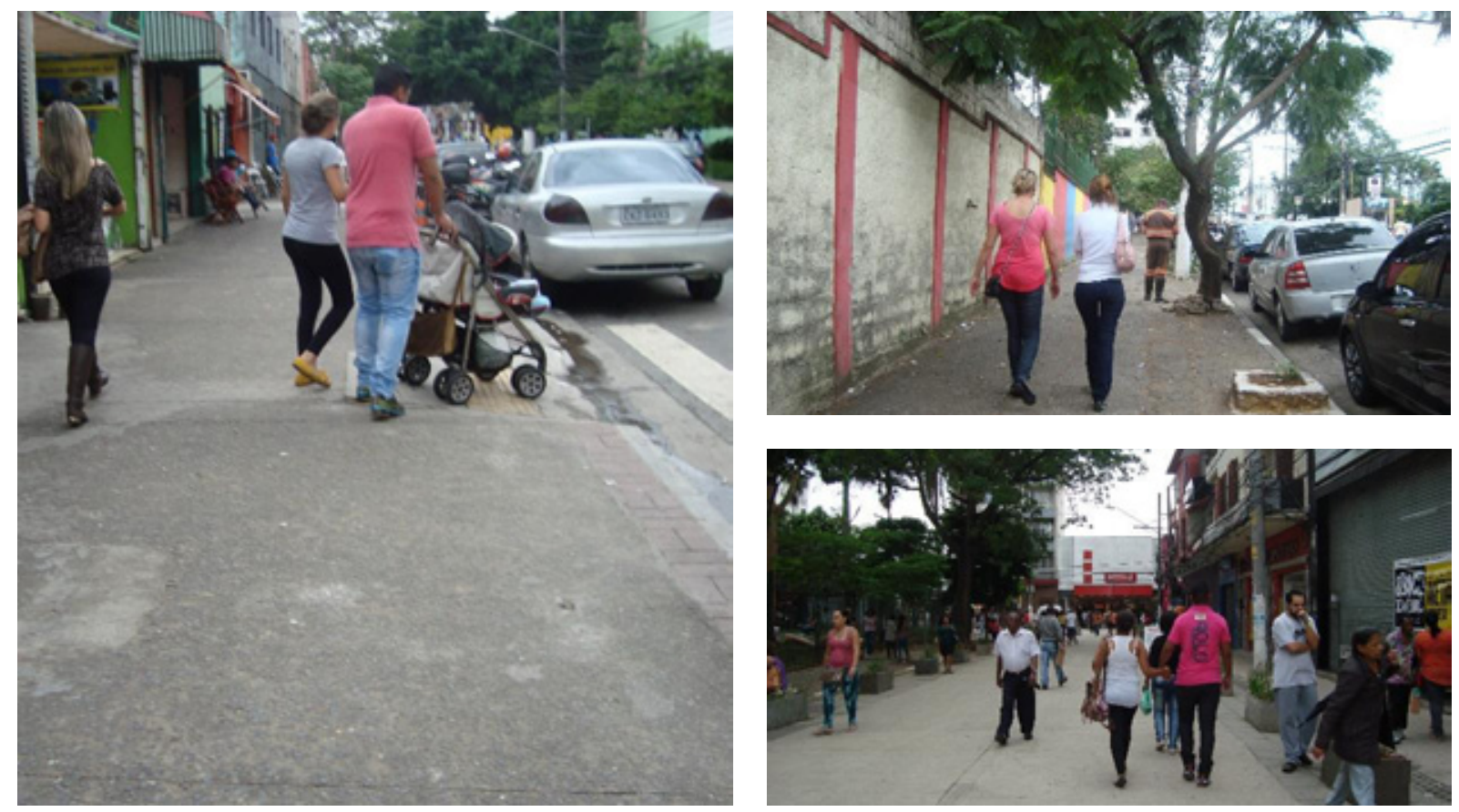

Figura 14 - Calçada COM Potencial de Adequação - Pessoa com carrinho de Bebê; Gestantes. Foto: Adrielli França. 2015 
Estas áreas com grande potencial parecem estar à espera da conscientização de seus cuidadores, os proprietários, ou apenas de uma aplicabilidade e fiscalização mais rigorosa da legislação em vigor, afinal é direito do cidadão não apenas ir e vir, mas ser servido de qualidade em todos os seus percursos.

\section{7 - CONSIDERAÇÕES FINAIS}

A qualidade do meio de deslocamento mais ecologicamente limpo (a calçada), e que deveria ser o mais utilizado pela população, encontra-se extremamente inadequada aos transeuntes dos espaços percorridos em análise. Reflexo este da falta de consenso entre os parâmetros legais, os responsáveis pela aplicabilidade e a prioridade quanto à mobilidade culturalmente difundida na metrópole, a qual ainda está longe de ser "o caminhar".

As questões levantadas no bairro Santo Amaro, infelizmente não é uma realidade fora do contexto da cidade de São Paulo; muito pelo contrário, a falta de segurança, conforto e fluidez é comum à cidade como um todo. A busca do entendimento das estrutura das calçadas já existentes no bairro está relacionada não somente aos seus diversos e numerosos usuários, mas também à carência de qualidades espaciais da cidade; e essa busca é, sem dúvida, o ponto de partida do estudo realizado.

Constatou-se que as áreas com grande potencial parecem estar à espera da conscientização de seus cuidadores, os proprietários, ou apenas de uma aplicabilidade e fiscalização mais rigorosa de nossas legislações em vigência, afinal é direito do cidadão não apenas ir e vir, mas ser servido de qualidade em qualquer que seja seu percurso.

\section{BIBLIOGRAFIA}

AMIRALIAN, Maria LT et al. Conceituando deficiência. Rev. Saúde Pública [online]. 2000, vol.34, n.1, pp. 97-103. ISSN 1518-8787. Disponível em: http://dx.doi. org/10.1590/S0034-89102000000100017 Acesso em: 10 de outubro de 2015.

BRASIL. Calçadas Paulistanas Você conhece o Passeio Livre? São Paulo/SP. 2009. Disponível em: http://www.vereadornatalini.com.br/site/sites/default/files/file/Cartilhas/ cartilhacalcadas.pdf Acesso em: 20 de outubro de 2015. 
BRASIL. Plano Diretor Estratégico de São Paulo 2014 Texto llustrado. Disponível em: http://gestaourbana.prefeitura.sp.gov.br/texto-da-lei-com-hyperlinks/. Acesso em: 10 de outubro de 2015.

BRASIL. Calçadas - O direito de ir e vir começa na porta da nossa casa. São Paulo/ SP. Disponível em: http://www.prefeitura.sp.gov.br/cidade/secretarias/subprefeituras/ calcadas/index.php?p=36935 Acesso em: 10 de outubro de 2015.

BRÖG, W., MENSE, N. Eight Cities Walking: Comparative Data on Walking as a Transport Mode from Cities in Europe, Australia and the US, Portland, sd.

BOARETO, Renato. Calçadas. Revista dos Transportes Públicos. ANTP, 2003. Disponível em: http://www.usp.br/nutau/CD/171.pdf Acesso em: 10 de outubro de 2015.

ECK,, R.W., Handbook of Transportation Engineering Pedestrians, Department of Civil and Environmental Engineering, West Virginia University, Morgantown, West Virginia, Copyright @ 2004 by The McGraw-Hill Companies, 2004.

FERREIRA, W. R., SHIMOISHI, J. M., A Segregação do Pedestre nas Cidades de Porte Médio, 1996, In: Anais do X Congresso Associação Nacional de Pesquisa e Ensino Transportes - ANPET, v.I, Brasília.

FIGUEIREDO, C. F.; MAIA, M. L. A. O Pedestre e seu Ambiente de Circulação: Condições e Avaliação dos Deslocamentos a Pé nas Cidades. Universidade Federal de Pernambuco. Recife/PE. Disponível em http://www.antp.org.br/_5dotSystem/ download/dcmDocument/2013/10/06/4D359BE4-AAD1-41F6-953C-54F7C9B9CCBF. pdf Acesso em: 10 de outubro de 2015.

GEHL, J.; Cidades Para Pessoas. Editora Perspectiva. $2^{a}$ edição. pag. 121 Dinamarca. 2014.

GOLD; P. A., Melhorando as Condições de Caminhada em Calçadas, Gold Projects, 2003.

JACOBS, J., Morte e Vida de Grandes Cidades, $3^{a}$ edição. São Paulo: Editora WMF Martins Fontes, 2011. pg. 29.

LEIVA, G. C., BARBOSA; H. M., Nível de Qualidade da Via Para Ciclistas - Uma Análise sobre o Ambiente Urbano, In: Anais do XVII Congresso da Associação Nacional de 
Pesquisa e Ensino Transportes - ANPET, Rio de Janeiro, 2003. Disponível em: http:// www.antp.org.br/_5dotSystem/download/dcmDocument/2013/10/06/4D359BE4AAD1-41F6-953C-54F7C9B9CCBF.pdf. Acesso em: 10 de outubro de 2015.

MELO, L. B. DE, TORRES, A. C. S., JACQUES, M. A. P., Estudo dos Fatores que afetam a Velocidade de Caminhada em Faixas de Pedestres Localizadas em Rodovias, Anais do XVIII Congresso da Associação Nacional de Pesquisa e Ensino Transportes - ANPET, Florianópolis, 2004.

MORATO, R.G.; KAWAKUBO, F. S. et al.; Avaliação da Desigualdade Ambiental na Subprefeitura de Santo Amaro - São Paulo/SP por meio de Geoprocessamento. ABEP, Caxambu- MG - Brasil, de 20- 24 de Setembro de 2004.

MOUDON, A. V., HESS, P. M., SNYDER, M. C. and STANILOV, K., Effects of Site Design on Pedestrian, Travel in Mixed-Use, Medium-Density Environments, Transportation Research Record, 1578, Paper No. 971360, Pag 48-55, sd. Disponível em: http:// www.antp.org.br/_5dotSystem/download/dcmDocument/2013/10/06/4D359BE4AAD1-41F6-953C-54F7C9B9CCBF.pdf Acesso em: 10 de outubro de 2015.

OSHIRO, F. S.; SILVEIRA, K. J.; VICENTE, R. V. A circulação na cidade de São Paulo: Planejamento ou improviso? Presidente Prudente/Sp. 2009. Disponível em: http://observatoriogeograficoamericalatina.org.mx/egal12/Geografiasocioeconomica/Geografiaurbana/225.pdf Acesso em: 16 de outubro de 2015.

PONCIANO, L.; 450 Bairros São Paulo 450 Anos. $2^{a}$ Edição. São Paulo: Editora Senac. São Paulo, p. 249-251. 2004.

SCHLICKMANN, M. P.; Caos Planejado. 2014. Disponível em: http://caosplanejado. com/ruas-para-pedestres/ Acesso em: 12 de outubro de 2015.

SILVA, A. S., LARA R., A Reconquista da Rua como Lugar de Convívio Social, In: $1^{\circ}$ Congresso Luso Brasileiro para o Planejamento Urbano Regional Integrado e Sustentável, São Carlos, SP, 2005.

SMPDS - Secretaria Municipal de Planejamento e Desenvolvimento Sustentável. Projeto Calçada Acessível [Guia para projetos de espaços públicos]. Seropédica/RJ. 2012. Disponível em: http://solucoesparacidades.com.br/wp-content/uploads/2013/04/ Nova-Cartilha.pdf 


\section{ANEXO}

\section{FICHA DE ANÁLISE DE CAMPO}

TIPO DE PEDESTRE:

\begin{tabular}{|c|c|c|c|}
\hline [ ] Cadeirante & [ ] Deficiente Intelectual & [ ] Obeso & [ ] Sem limitações Físicas \\
\hline [ ] Deficiente Auditivo & [ ] Idoso & [ ]Criança & \\
\hline [ ] Deficiente Visual & [ ] Gestante & $\begin{array}{l}\text { [ ] Pessoa com Carrinho } \\
\text { de Bebê }\end{array}$ & \\
\hline
\end{tabular}

ORIGEM E DESTINO:

TEMPO DE PERCURSO:

DIFICULDADES ENCONTRADAS:

QUALIDADE DAS ÁREAS PECORRIDAS:

1- Acessibilidade - Assegurar completa mobilidade aos usuários, sobretudo pessoas com deficiência ou com mobilidade reduzida;
[ ] Atende
[ ] Atende Parcialmente
[ ] Não Atende

2- Dimensionamento - Atendendo às normas técnicas quanto a largura mínima e inclinaçăo transversal;
[ ] Atende
[ ] Atende Parcialmente
[ ] Não Atende

3- Qualidade - Atributo que qualifica a percepção do passeio no entorno criando uma identidade espacial;
[ ] Atende
[ ] Atende Parcialmente
[ ] Não Atende

4- Segurança- Proporcionar segurança ao ato de andar, ou seja, por meio de materiais de revestimento adequados como também pela boa distribuição de seus mobiliários, dos elementos urbanos e iluminação pública;
[ ] Atende
[ ] Atende Parcialmente
[ ] Nåo Atende

5- Continuidade - Constituir rota de deslocamento acessivel aos pontos de maior interesse coletivo, guardando seus. aspectos estéticos e funcionais em harmonia;
[ ] Atende
[ ] Atende Parcialmente
[ ] Não Atende

6- Espaço de socialização - Propiciar espaços de encontro e interação entre pessoas;
[ ] Atende
[ ] Atende Parcialmente
[ ] Năo Atende

7- Desenho da paisagem - Organização de todos os elementos das vias de modo a torná-las ambientalmente confortáveis, propiciando micro-climas agradáveis e conforto visual.
[ ] Atende
[ ] Atende Parcialmente
[ ] Não Atende

8- Permeabilidade - As calçadas hoje podem contribuir na drenagem das águas sendo permeáveis ou drenantes. basta escolher o material adequado e preparar uma base para absorver estas águas.
[ ] Atende
[ ] Atende Parcialmente
[ ] Não Atende

9- Arborizaçăo-É preciso combater as chamadas "ilhas de calor" que se formam onde o solo é impermeabilizado e falta arborizaçăo. Para isso é importante plantar árvores onde for possivel.
[ ] Atende
[ ] Atende Parcialmente
[ ] Não Atende

10- Beleza - Uma rua fica mais bonita e humana quando suas calçadas são acessíveis e padronizadas.
[ ] Atende
[ ] Atende Parcialmente
[ ] Não Atende 